\title{
Sistem Informasi Akuntansi Pembelian sebagai Pengendalian Internal Risiko Penyalahgunaan Aset (Studi kasus PT Sumber Alfaria Trijaya Tbk)
}

\author{
Hasna Lathifah Kusumawati* \\ E-mail: hasnalathifahk12@gmail.com \\ Program Studi Pendidikan Akuntansi, Universitas Sebelas Maret, Surakarta, Indonesia
}

\begin{abstract}
Abstrak
Sistem informasi akuntansi memiliki peran yang vital dalam sebuah usaha, baik dari tingkat yang masih kecil hingga yang besar, dalam hal ini sebagai pengendalian internal berfungsi dalam tiga fase yaitu preventif, deteksi, dan korektif. Dalam artikel ini mengambil studi kasus PT Sumber Alfaria Trijaya Tbk, dengan menganalisis pada siklus pembelian secara umum. Tujuan pembuatan artikel ini yaitu, untuk mengetahui kemungkinan permasalahan yang terjadi pada siklus pembelian beserta risiko dan pengendalian yang bisa diajukan dalam sebuah pertimbangan manajemen. Hasil analisis ini menunjukkan bahwa kemungkinan terjadinya fraud yang dilakukan oleh pihak internal maupun eksternal. Oleh sebab itu pengendalian atas risiko yang mungkin terjadi perlu menjadi bahan pertimbangan oleh manajer dan akuntan, begitu juga pengendalian terhadap sistem komputer sebagai sumber informasi data laporan keuangan pada PT Sumber Alfaria Trijaya Tbk.
\end{abstract}

Kata Kunci: Informasi, siklus, risiko, pengendalian

\section{Pendahuluan}

Sebuah pengambilan keputusan di masa sekarang ini terpengaruh oleh kecepatan dan ketepatan informasi yang diterima. Informasi merupakan hal yang vital bagi perusahaan, karena kesuksesan perusahaan salah satu faktornya ada pada ketepatan keputusan yang diambil manajerial berdasarkan informasi yang ada di perusahaan tersebut. Informasi akuntansi manajemen dibutuhkan oleh manajemen salah satunya pada tahap penganalisaan konsekuensi tiap alternatif tindakan yang digunakan dalam pengambilan keputusan (Santi, 2013:912). Oleh karena itu manajemen perlu mendapatkan informasi yang akurat pada setiap elemen di perusahaan, perlunya filter pada setiap informasi yang diterima. Dalam hal ini, hasil analisis sistem informasi akuntansi dapat membantu manajemen untuk mendapatkan pengambilan keputusan yang tepat.

Sistem informasi akuntansi memiliki peran yang vital dalam sebuah usaha, baik dari tingkat yang masih kecil hingga yang besar. Sistem informasi akuntansi 
dalam hal ini sebagai pengendalian internal berfungsi dalam tiga fase yaitu preventif, deteksi, dan korektif. Dalam sebuah siklus pembelian tentu saja memiliki risiko yang perlu dikendalikan oleh pihak akuntan dan manajemen. Risiko yang memiliki probabilitas terjadinya tinggi yaitu penyalahgunaan aset. Penyalahgunaan aset tentu saja dapat merugikan pemilik usaha dan juga data laporan keuangan. Terlebih lagi apabila perusahaan tersebut sudah go-public dan data laporan keuangan tersebut dapat dengan mudah diakses oleh khalayak umum, termasuk investor dan kreditur yang berkepentingan dengan perusahaan bersangkutan.

Pengendalian internal dalam perusahaan merupakan salah satu fungsi utama sistem informasi akuntansi. Dengan demikian sistem informasi akuntansi harus menunjang pengendalian internal yang diterapkan oleh perusahaan (Darmawan et al, 2017:516). Pengendalian internal diperlukan untuk mengkoordinasi dan mengawasi jalannya aktivitas dalam perusahaan. Bertujuan untuk menghindari hal-hal yang dapat menyebabkan kerugian perusahaan seperti penyelewengan, kecurangan, pemborosan, dan pencurian dari pihak dalam maupun luar perusahaan dalam menilai perusahaan serta untuk mengevaluasi dan mengambil tindakan perbaikan dalam mengantisipasi kelemahan perusahaan (Yos, 2014 dalam Voets et al, 2016:192).

PT Sumber Alfaria Trijaya Tbk merupakan salah satu perusahaan besar yang bergerak di bidang perdagangan dan distribusi, yang saat ini sudah merambah ke sektor minimarket. Aktivitas yang kompleks dalam perusahaan ini tentunya rentan terjadi risiko pada beberapa aktivitasnya, terutama pada pembelian dan penjualan yang besar kemungkinan berhubungan dengan penyalahgunaan aset. Dengan demikian, perlunya sistem informasi akuntansi sebagai pengendalian internal untuk meminimalisir risiko yang akan terjadi.

Artikel ini bertujuan untuk mengetahui hasil analisis sistem informasi akuntansi pada siklus pembelian sebagai pengendalian internal untuk meminimalisirkan risiko yang terjadi akibat masalah penyalahgunaan aset pada PT Sumber Alfaria Trijaya Tbk, guna mendapatkan laporan keuangan yang sehat 
bebas dari kesalahan dan kecurangan serta menjaga sumber daya manusia PT Sumber Alfaria Trijaya Tbk dari perilaku penyelewengan.

\section{Sistem Informasi Akuntansi}

Menurut Romney dan Steinbart (2018:10), sistem informasi akuntansi adalah sistem yang dapat mengumpulkan, mencatat, menyimpan, dan memproses data untuk menghasilkan informasi bagi para pembuat keputusan

\section{Komponen Sistem Informasi Akuntansi}

Romney dan Steinbart (2018:11), ada enam komponen dari sistem informasi akuntansi, yaitu sebagai berikut:

1. Orang yang menggunakan sistem

2. Prosedur dan instruksi yang digunakan untuk mengumpulkan, memproses, dan menyimpan data

3. Data mengenai organisasi dan aktivitas bisnisnya

4. Perangkat lunak yang digunakan untuk mengolah data

5. Infrastruktur teknologi informasi, meliputi computer, perangkat peripheral, dan perangkat jaringan komunikasi yang digunakan dalam SIA

6. Pengendalian internal dan pengukuran keamanan yang menyimpan data SIA.

\section{Sistem Pengendalian Internal}

Menurut Mulyadi, sistem pengendalian intern meliputi struktur organisasi, metode dan ukuran-ukuran yang dikoordinasikan untuk menjaga organisasi, mengecek ketelitian dan keandalan data akuntansi, mendorong efesiensi dan mendorong dipatuhinya kebijakan manajemen (Darmawan et al, 2017:517).

\section{Fraud}

Menurut Romney dan Steinbart (2018:130-132), fraud merupakan sebuah cara yang digunakan seseorang untuk mendapatkan keuntungan yang tidak adil atas orang lain, termasuk pernyataan, representasi, atau pengungkapan palsu. Fraud ini termasuk dalam kejahatan kerah putih. Kategori Fraud, antara lain:

1. Penyalahgunaan aset 
2. Pelaporan keuangan yang curang

\section{Siklus Pembelian}

Di dalam siklus pembelian ini, masing-masing aktivitas di dalam siklus tersebut dapat menyebabkan risiko terjadinya fraud, terutama dalam penyalahgunaan aset. Sistem transaksi pembelian ini berawal dari proses pembelian untuk mengisi persediaan barang dagang dari supplier hingga masuk ke dalam gudang dan minimarket.

\section{Hasil dan Pembahasan}

\section{Analisis Proses Bisnis Transaksi Pembelian}

Kegiatan dalam siklus pembelian pada PT Sumber Alfaria Trijaya Tbk:

1. Bagian gudang mengecek persediaan kosong dan mengonfirmasi pada bagian pembelian dan manajer untuk mengisi stok barang

2. Pengisian stok barang oleh supplier

Permasalahan yang terjadi pada siklus pembelian yaitu proses pembelian dan penyimpanan barang dagang. Sedangkan risiko yang terjadi pada siklus pembelian:

1. Adanya pembelian fiktif oleh bagian pembelian

2. Penggelapan barang dagang oleh bagian gudang

3. Memasukkan barang tidak layak jual oleh supplier

4. Manipulasi sistem

\section{Usulan Pengendalian Siklus Pembelian}

Atas risiko-risiko yang terjadi karena munculnya permasalahan pada proses pembelian dan penyimpanan barang dagang. Usulan pengendalian atas setiap risiko yang terjadi antara lain:

1. Karena adanya risiko nomor satu maka pengendaliannya yaitu, manajer dan akuntan harus teliti atas data laporan keuangan yang masuk, pengecekan secara berkala oleh bagian gudang atas pembelian yang dilakukan bagian pembelian dapat dilakukan secara berkala.

2. Upaya pengendalian atas risiko nomor dua dapat dilakukan dengan cara, pengecekan data persediaan barang dagangan oleh masing-masing bagian 
gudang dan juga manajer. Pembelian persediaan diusahakan sampai stok barang dagang benar-benar habis.

3. Atas risiko nomor tiga maka usulan pengendaliannya yaitu, bagiam gudang perlu mengecek detail setiap barang yang masuk dari supplier. Bagian pembelian memilih supplier produk untuk menyetok barang dagang yang memiliki rating baik secara umum.

4. Upaya pengendalian atas risiko nomor empat dapat dilakukan dengan cara memperkuat sistem komputer dengan izin akses yang sulit, jika upaya untuk mengganti informasi terkait maka perlu meminta izin akses atasan yang mana harus mendapatkan izin terlebih dahulu. Transparasi sistem informasi juga diperlukan untuk pengendalian risiko ini.

\section{Simpulan}

Dalam sebuah proses bisnis di dalam skala usaha kecil hingga besar tentu rentan atas fraud. Oleh sebab itu sistem informasi akuntansi perlu turut andil untuk dapat mengendalikan secara internal dalam risiko yang mungkin terjadi. Pada PT Sumber Alfaria Trijaya Tbk, siklus pembelian rentan terjadi fraud penyalahgunaan aset oleh karena itu pengendalian yang perlu dilaksanakan baik oleh manajer, akuntan, bagian gudang, dan bagian pembelian masing-masing memiliki peran dalam upaya tersebut, begitu juga pengendalian terhadap sistem komputer sebagai sumber informasi data laporan keuangan pada perusahaan tersebut.

\section{Referensi}

Santi, G. (2013). Sistem Informasi Akuntansi Manajemen Dalam Pengambilan Keputusan Investasi Pada PT. Bank Sulut Cabang Marina Plaza. Jurnal EMBA, 1(3), 912.

Darmawan, R., Mahsina, \& Susanti, W. (2017). Analisis Penerapan Sistem Informasi Akuntansi Penjualan dalam Rangka Meningkatkan Pengendalian Intern dan Efektivitas Penjualan pada PT Sumber Alfaria Trijaya Tbk. EJournal Akuntansi “Equity”, 3(2), 516-517. 
Voets, F.O., Sondakh, J.J. \& Wangkar A. (2016). Analisis Sistem Informasi Akuntansi Siklus Penjualan dan Penerimaan Kas untuk Meningkatkan Pengendalian Intern pada PT Sumber Alfaria Trijaya Tbk (Alfamart) Cabang Manado. Jurnal Berkala Ilmiah Efisiensi, 16(4), 192.

Romney, M.B. \& Steinbart, P.J. (2018). Accounting Information Systems (Fourteenth Edition). New York: Pearson Education Inc.

\section{*Data Penulis}

Hasna Lathifah Kusumawati, yang berasal dari Banjarnegara, Jawa Tengah, lahir pada tanggal 12 Agustus 2001, kini sedang menempuh studi di Universitas Sebelas Maret pada program studi Pendidikan Akuntansi semester 5.

Kontak:

Hp/WA : 082375252911

Email : hasnalathifahk12@gmail.com 